\title{
Usefulness of plasma renin activity in predicting haemodynamic and clinical responses and survival during long term converting enzyme inhibition in severe chronic heart failure Experience in 100 consecutive patients
}

\author{
MILTON PACKER, NORMA MEDINA, MADELINE YUSHAK, WAI HUNG LEE \\ From the Division of Cardiology, Department of Medicine, Mount Sinai School of Medicine of The City \\ University of New York, New York, USA
}

SUMMARY The relation between plasma renin activity before treatment and the haemodynamic and clinical responses to converting enzyme inhibition was determined in 100 consecutive patients with severe chronic heart failure who were treated with captopril or enalapril. Initial doses of captopril produced significant increases in cardiac index and decreases in left ventricular filling pressure, mean arterial pressure, mean right atrial pressure, heart rate, and systemic vascular resistance that varied linearly with the pretreatment value for plasma renin activity. In contrast, there was no relation between the pretreatment activity and the magnitude of haemodynamic improvement after 1-3 months of treatment with the converting enzyme inhibitors, and, consequently, a similar proportion of patients with a high $(>6 \mathrm{ng} / \mathrm{ml} / \mathrm{h} ;>4.62 \mathrm{mmol} / \mathrm{l} / \mathrm{h})$, intermediate $(2-6 \mathrm{ng} / \mathrm{ml} / \mathrm{h} ; 1.54-4.62 \mathrm{mmol} / \mathrm{l} / \mathrm{h})$, and low $(<2 \mathrm{ng} / \mathrm{ml} / \mathrm{h} ;<1.54 \mathrm{mmol} / \mathrm{l} / \mathrm{h})$ pretreatment value improved clinically during long term treatment $(64 \%, 60 \%$, and $64 \%$ respectively). Long term survival after one, two, and three years was similar in the three groups. Estimating the degree of activation of the renin-angiotensin system by measuring pretreatment plasma renin activity fails to predict the long term haemodynamic or clinical responses to converting enzyme inhibitors in patients with severe chronic heart failure, and thus appears to be of limited value in selecting those patients likely to benefit from treatment with these drugs.

Although inhibition of the angiotensin converting enzyme with captopril and enalapril is of established value in the management of severe chronic heart failure, ${ }^{1}$ there is no reliable means of selecting patients who are likely to improve during long term treatment with these drugs. Previous trials have indicated that $60-65 \%$ of patients with heart failure will benefit haemodynamically and clinically after 1-3 months' treatment with these agents, ${ }^{1-4}$ but responders and non-responders do not appear to

Requests for reprints to Dr Milton Packer, Division of Cardiology, Mount Sinai Medical Center, 1 Gustave Levy Place, New York, New York 10029, USA.

Accepted for publication 26 April 1985 differ with regards to pretreatment demographic, haemodynamic, or clinical variables. ${ }^{2}$ Because of the ability of converting enzyme inhibitors to interfere with the renin-angiotensin system early investigators suggested that the responses to captopril and enalapril could be predicted by assessing plasma renin activity before treatment was started. ${ }^{5-8}$ Subsequent studies, however, found little relation between plasma renin activity and haemodynamic response and questioned the value of hormonal measurements as a means of selecting patients likely to benefit from treatment. ${ }^{9-11}$ A major drawback of all of these previous studies is that they evaluated only the immediate effects of converting enzyme inhibition in small numbers of patients; unfortunately, short term haemodynamic assessments 
of patients treated with captopril and enalapril are of limited value in predicting long term clinical outcome. ${ }^{12-14}$ No previous study has examined the usefulness of plasma renin activity in predicting the long term haemodynamic and clinical responses to these drugs in a large series of patients.

In this study we evaluated the relation between plasma renin activity and the haemodynamic and clinical effects of long term converting enzyme inhibition in 100 consecutive patients with severe chronic heart failure.

\section{Patients and methods}

The study population consisted of 100 (70 men, 30 women; aged $27-83$ (mean 64 ) years) consecutive patients with severe chronic heart failure who received treatment with the converting enzyme inhibitors, captopril or enalapril, for at least two weeks and who had their plasma renin activity determined before the start of treatment. The cause of heart failure was ischaemic heart disease in 68 patients, primary myocardial disease in 25 , and primary mitral or aortic valve regurgitation, or both, associated with severe left ventricular dysfunction in seven, four of whom had undergone valve replacement surgery. All patients had symptoms at rest or on minimal exertion but were evaluated while clinically stable.

\section{HAEMODYNAMICASSESSMENT}

Each patient received treatment with converting enzyme inhibitors under controlled conditions. For at least five days before entry into the study doses of digoxin and diuretics remained constant, all previous vasodilator drugs were withdrawn, and patients consumed a $2 \mathrm{~g}$ sodium diet. After completion of the initial observation period right heart catheterisation was performed with a triple lumen flow directed thermodilution catheter for the measurement of intracardiac pressures, and an arterial cannula was inserted into the radial artery to measure systemic pressures. Thermodilution cardiac outputs were determined in triplicate by a bedside cardiac output computer using iced injectate. Heart rates were derived from a continuously recorded electrocardiogram.

The following haemodynamic variables were determined repeatedly to ensure stability of the pretreatment state before drug administration: mean arterial pressure, heart rate, pulmonary artery and pulmonary capillary wedge pressures, mean right atrial pressure, and cardiac output. Each of the 100 patients received an initial dose of $25 \mathrm{mg}$ of captopril orally, after which all haemodynamic variables were determined every 30 minutes for three hours.
Patients were then treated with either captopril (75-450 mg daily, 86 patients) or enalapril $(20-40 \mathrm{mg}$ daily, 14 patients) for the next 1-3 months, during which time doses of digitalis, diuretics, and converting enzyme inhibitors remained unaltered and a $2 \mathrm{~g}$ sodium diet was maintained. At the end of the treatment period right heart catheterisation and arterial cannulation were again performed in 83 patients to assess the long term haemodynamic response to treatment; 17 patients did not undergo repeat evaluation because of death (three patients), refusal (three patients), a change in diuretic dosage (five patients), or physician preference (six patients). The protocol for the second haemodynamic evaluation was identical in all respects to that followed for the first study; haemodynamic variables were measured during uninterrupted treatment for three hours after the administration of captopril and for 4-6 hours after the administration of enalapril.

\section{HORMONAL AND CLINICAL \\ DETERMINATIONS}

Blood samples for determining plasma renin activity by radioimmunoassay were collected just before the initial dose of captopril. All samples were drawn at a similar time of day, while the patient was receiving a constant $2 \mathrm{~g}$ sodium diet, after 4-12 hours lying supine, and 12-24 hours after taking the last dose of diuretic. Under these conditions, the reproducibility of our determinations of plasma renin activity in $\mathbf{5 2}$ patients with congestive heart failure on consecutive days was excellent: $r=0.89$ for $\log _{e}\left(\right.$ day $\left._{2} P R A\right)$ $=0.88 \times \log _{\mathrm{e}}\left(\right.$ day $\left._{1} \mathrm{PRA}\right)+0.15$, where PRA is plasma renin activity.

Changes in the clinical state of each patient after 1-3 months' treatment with captopril or enalapril were assessed in relation to the presence or absence of dyspnoea and fatigue at rest and during daily activities. Patients who improved clinically after 1-3 months continued to receive these drugs in addition to digitalis and diuretics. Patients who did not improve continued to receive treatment with the converting enzyme inhibitors according to the preference of their referring doctor. Patients who experienced adverse reactions were treated with lower doses of these drugs (after the side effect had subsided); treatment was stopped if the adverse reaction recurred with rechallenge. All patients were reassessed clinically at intervals of 1-2 months. Long term survival was assessed from the first day of treatment to July 1984; follow up data were available in 97 of 100 patients.

\section{DATA ANALYSIS}

Mean systemic arterial pressures were determined by electronic filtration. Left ventricular filling pres- 
Table 1 Correlation coefficients for the relation between plasma renin activity and changes in various haemodynamic variables after first doses of captopril and after long term converting enzyme inhibition

\begin{tabular}{lll}
\hline Variables & First dose & Long term \\
\hline Cardiac index & $0.49^{\star}$ & 0.09 \\
Left ventricular filling & $0.47^{\star}$ & 0.19 \\
pressure & $0.45^{\star}$ & $0.27^{\star \star}$ \\
$\begin{array}{l}\text { Mean arterial pressure } \\
\text { Mean right atrial }\end{array}$ & $0.34^{\star}$ & 0.18 \\
$\begin{array}{l}\text { pressure } \\
\text { Heart rate }\end{array}$ & $0.28^{\star \star}$ & 0.10 \\
$\begin{array}{l}\text { Systemic vascular } \\
\text { resistance }\end{array}$ & $0.46^{\star}$ & 0.19 \\
\hline $\begin{array}{l}{ }^{\star} \mathrm{p}<0.001 ;{ }^{\star} \mathrm{p}<0.05 ; \text { levels of significance for correlation } \\
\text { coefficients }(\mathrm{r})\end{array}$
\end{tabular}

sure was measured as the mean pulmonary capillary wedge pressure or as the pulmonary artery diastolic pressure after it had been shown to be identical with wedge pressure. Derived haemodynamic variables were calculated as follows: cardiac index $=\mathrm{CO} /$ body surface area $\left(1 / \mathrm{min}\right.$ per $\left.\mathrm{m}^{2}\right)$ and systemic vascular resistance $=80 \times(\mathrm{MAP}-\mathrm{MRAP}) / \mathrm{CO}\left(\mathrm{dyn} \mathrm{s} \mathrm{cm} \mathrm{cm}^{-5}\right)$ where $\mathrm{CO}$ is cardiac output, MAP mean arterial pressure, and MRAP mean right atrial pressure.

During both short term and long term treatment, the haemodynamic responses to converting enzyme inhibition were assessed at peak drug effect on left ventricular filling pressure and systemic vascular resistance $(1 \cdot 0(0 \cdot 5) \mathrm{h}$ after captopril and $3 \cdot 0(1 \cdot 0) \mathrm{h}$ after enalapril).

Patients were divided into three groups based on their pretreatment plasma renin activity: low $(<2 \mathrm{ng} / \mathrm{ml} / \mathrm{h} ; \quad<1.54 \mathrm{mmol} / \mathrm{l} / \mathrm{h})$, intermediate (2-6 ng/ml $/ \mathrm{h} ; 1.54-4.62 \mathrm{mmol} / \mathrm{l} / \mathrm{h})$, and high $(>6 \mathrm{ng} / \mathrm{ml} / \mathrm{h} ;>4.62 \mathrm{mmol} / \mathrm{l} / \mathrm{h}$ ). These ranges were based on normal values in our laboratory $(2-6 \mathrm{ng} / \mathrm{ml} / \mathrm{h}(1.54-4.62 \mathrm{mmol} / \mathrm{l} / \mathrm{h})$ while the patient was lying supine and taking a salt restricted diet), and is similar to the classification scheme used by others. ${ }^{1516}$ Qualitative and quantitative differences between the three groups were compared by the $\chi^{2}$ test and by one way analysis of variance respectively. The hypotheses that plasma renin activity and the haemodynamic responses to treatment were significantly related were tested by least squares linear regression analysis. Survival curves were calculated by life table analytical methods. Group data are expressed as mean (standard error of the mean).

\section{Results}

HAEMODYNAMICRESPONSES TO CONVERTING ENZYME INHIBITION

First doses of captopril produced significant $(p<0.001)$ increases in cardiac index and decreases in left ventricular filling pressure, mean arterial pres- sure, mean right atrial pressure, heart rate, and systemic vascular resistance that varied linearly $(p<0.05$ to 0.001$)$ with the pretreatment plasma renin activity (Table 1 and Fig. 1). In contrast, there was no correlation between pretreatment plasma renin activity and the magnitude of the haemodynamic response to long term converting enzyme inhibition (Fig. 1, Table 1). Only the weak correlation between plasma renin activity and the long term decrease in mean arterial pressure $(r=0.27)$ was significant $(p<0.05)$, and this was because of the large number of patients studied.

\section{CLINICAL RESPONSES TO CONVERTING}

ENZYME INHIBITION

After 1-3 months' treatment, 23 of 36 (64\%) patients with low plasma renin activity, 25 of $42(60 \%)$ 은 patients with intermediate activity, and 14 of $22-$ $(64 \%)$ patients with high activity improved clinically $\infty$ by at least one New York Heart Association functional class. Pretreatment haemodynamic and clinical variables in these three groups were similar, except for a slightly lower heart rate in patients with low activity $(\mathrm{p}<0.05$ vs groups with intermediate and high activity) (Table 2). After 6, 12, 18, 24, 30, and 36 months long term survival in the low, intermediate, and high activity groups was similar (Fig. 2). All but 18 of 100 patients had received treatment with captopril or enalapril until their most recent follow up visit or until within four weeks of their death.

\section{Discussion}

The findings of the present study indicate that the pretreatment measurement of plasma renin activity cannot be used to select patients with severe chronic heart failure who will benefit from long term treatment with converting enzyme inhibitors. Although plasma renin activity varied linearly to a modest but significant degree with the immediate response to captopril, it did not correlate with the haemodynamic effects of long term treatment. Categorisation of patients into high, intermediate, and low activity groups did not predict long term clinical $N$ benefits or survival. There appears, therefore, to be $N$ little reason for measuring plasma renin activity $N$ before treatment is started with converting enzyme inhibitors in patients with congestive heart failure.

In so far as plasma renin activity is an accurate $\stackrel{\circ}{C}$ marker of angiotensin dependent vasoconstriction, $\stackrel{\mathbb{Q}}{\rightarrow}$ we were not surprised to find a significant relation between plasma renin activity and the haemodynamic responses to first doses of captopril. $\mathbb{\Phi}^{+}$ Similar findings have been reported by others ${ }^{5-8} ; \frac{?}{\mathrm{D}}$ the failure of some investigators to confirm these 

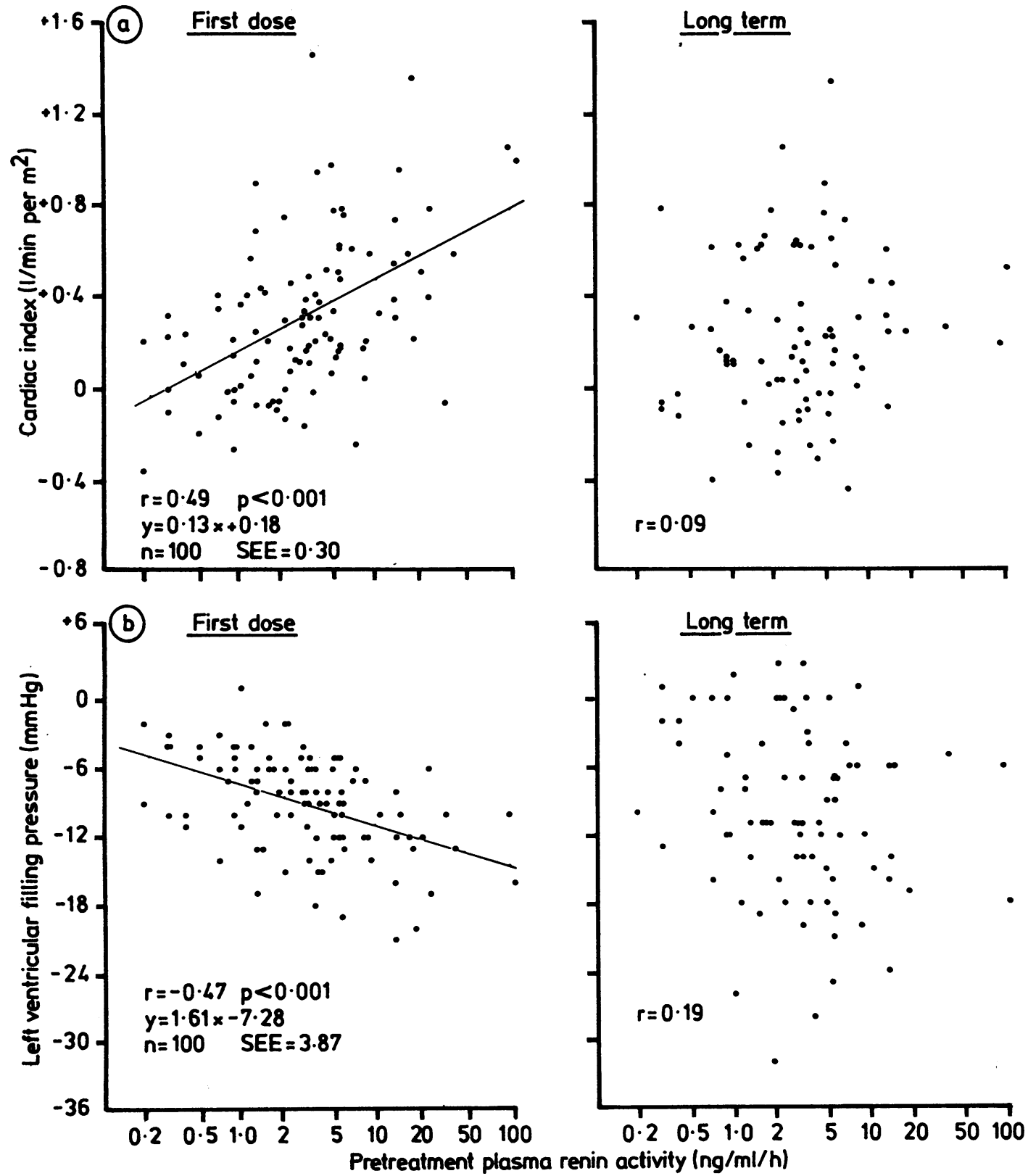

Fig 1 Relation between pretreatment plasma renin activity and changes in (a) cardiac index and (b) left ventricular filling pressure after first doses of captopril and long term converting enzyme inhibition in patients with severe chronic heart failure. A significant relation was noted for both variables after first doses but not during long term treatment. Conversion: traditional to SI units_plasma renin activity: $1 \mathrm{ng} / \mathrm{ml} / \mathrm{h} \approx 0.77 \mathrm{mmol} / \mathrm{l} / \mathrm{h}$. 
Table 2 Pretreatment haemodynamic and clinical variables in patients with heart failure grouped according to values for plasma renin activity before converting enzyme inhibition. Values are mean (SEM) unless stated otherwise

\begin{tabular}{|c|c|c|c|c|}
\hline Variables & $\begin{array}{l}\text { Low } \\
(<2 \mathrm{ng} / \mathrm{ml} / \mathrm{h})\end{array}$ & $\begin{array}{l}\text { Intermediate } \\
(2-6 \mathrm{ng} / \mathrm{ml} / \mathrm{h})\end{array}$ & $\begin{array}{l}\text { High } \\
(>6 n g / m l / h)\end{array}$ & pvalue * \\
\hline $\begin{array}{l}\text { Age }(y r) \\
\text { No. of patients }(M / F)\end{array}$ & $\begin{array}{l}66.9(1.8) \\
25 / 11\end{array}$ & $\begin{array}{l}61 \cdot 7(2 \cdot 0) \\
30 / 12\end{array}$ & $\begin{array}{c}65 \cdot 6(1 \cdot 7) \\
15 / 7\end{array}$ & $\begin{array}{l}\text { NS } \\
\text { NS }\end{array}$ \\
\hline $\begin{array}{l}\text { Ischaemic heart disease } \\
\text { Primary cardiomyopathy } \\
\text { Primary valve disease } \\
\text { Cardiac index }\left(1 / \text { min per } \mathrm{m}^{2}\right) \\
\text { Left ventricular filling pressure }(\mathrm{mm} \mathrm{Hg}) \\
\text { Mean arterial pressure }(\mathrm{mm} \mathrm{Hg}) \\
\text { Mean right atrial pressure }(\mathrm{mm} \mathrm{Hg}) \\
\text { Heart rate (beats/min) } \\
\text { Systemic vascular resistance }\left(\text { dyn } \mathrm{s} \mathrm{cm}^{-5}\right)\end{array}$ & $\begin{array}{l}21 \\
12 \\
3 \\
1 \cdot 78(0 \cdot 08) \\
25 \cdot 7(0 \cdot 7) \\
87 \cdot 1(2 \cdot 7) \\
11 \cdot 4(1 \cdot 0) \\
80 \cdot 7(2 \cdot 0) \\
2110(133)\end{array}$ & $\begin{array}{l}29 \\
9 \\
4 \\
1 \cdot 81(0 \cdot 07) \\
26 \cdot 5(0 \cdot 7) \\
82 \cdot 2(2 \cdot 0) \\
11 \cdot 6(0 \cdot 9) \\
86 \cdot 7(2 \cdot 0) \\
1908(80)\end{array}$ & $\begin{array}{l}18 \\
4 \\
0 \\
1 \cdot 64(0 \cdot 06) \\
27 \cdot 7(0 \cdot 9) \\
78 \cdot 8(2 \cdot 9) \\
12 \cdot 3(1 \cdot 5) \\
88 \cdot 8(3 \cdot 3) \\
2019(147)\end{array}$ & $\begin{array}{l}\text { NS } \\
\text { NS } \\
\text { NS } \\
\text { NS } \\
\text { NS } \\
\text { NS } \\
\text { NS } \\
<0.05 \\
\text { NS }\end{array}$ \\
\hline
\end{tabular}

^Significance of difference between the three groups.

Conversion: traditional to SI units - plasma renin activity: $1 \mathrm{ng} / \mathrm{ml} / \mathrm{h} \approx 0.77 \mathrm{mmol} / \mathrm{l} / \mathrm{h}$.

observations was probably related to their evaluation of small numbers of patients with a narrow range of values for plasma renin activity..$^{-11}$ The relation that we found between plasma renin activity and short term response, however, was not as striking as has been reported previously, ${ }^{5-8}$ partly because many of our patients with low plasma renin activity showed pronounced early haemodynamic effects. This unexpected response may be related to the ability of converting enzyme inhibitors to interact with other hormonal systems, ${ }^{17-19}$ or to the ability of renin and angiotensin to act as local tissue hormones, so that circulating concentrations of these substances may not reflect their concentration at active sites in the peripheral vasculature. ${ }^{2021}$

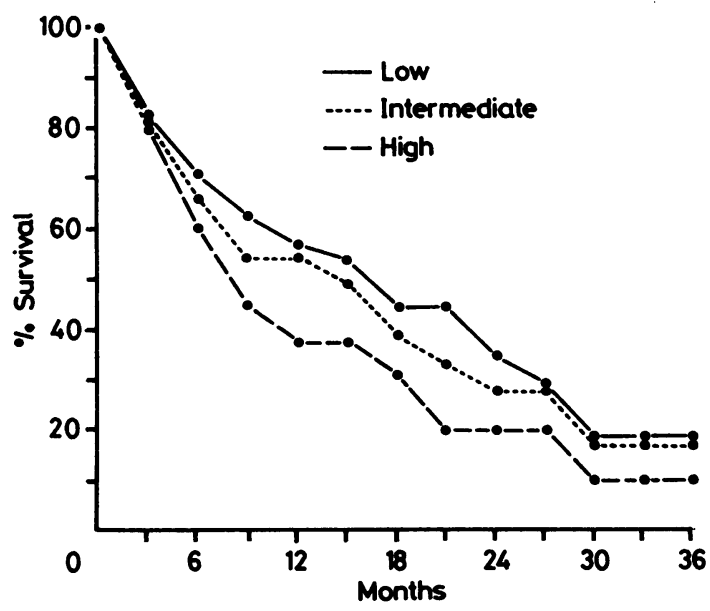

Fig. 2 Long term survival in patients with severe chronic heart failure treated with converting enzyme inhibitors grouped into low $(n=36)$, intermediate $(n=42)$, and high renin $(n=22)$ cohorts. The small differences in survival between the groups were not significant.
The modest relation that we found between pretreatment plasma renin activity and the initial hae- $\infty$ modynamic effects of captopril was no longer seen after 1-3 months of converting enzyme inhibition; a similar time dependent dissociation between haemodynamic and hormonal variables has been noted in hypertensive subjects. ${ }^{223}$ These observations can be explained by our previous finding that the magnitude of the response to converting enzyme inhibition can change dramatically during the course of treatment. Some patients with heart failure who respond initially to captopril fail to show sustained effects with prolonged treatment; conversely, many patients who do not respond initially benefit only during long term treatment. ${ }^{12}$ This delayed response to converting enzyme inhibition is common in patients with heart failure ${ }^{12}$ and may result from the reversal of a slow pressor response to angiotensin, ${ }^{2324}$ from a diuretic effect of captopril and enalapril that follows their suppression of aldosterone, ${ }^{612}$ or from the ability of these drugs to produce a long term reduction in the circulating concentrations of other vasoconstrictor hormones (catecholamines and vasopressin). ${ }^{1819}$ All these factors (acting alone or in concert) probably explain why the 옹 haemodynamic response to first doses of captopril $D$ bears little relation to its haemodynamic effects during long term treatment and thus fails accurately to predict the clinical response to long term converting enzyme inhibition. ${ }^{12-14}$

Our finding that plasma renin activity did not pre- $\mathcal{\omega}$ dict long term survival in our patients with severe heart failure is of interest. Massie and coworkers $\bullet$ have shown that one of the principal prognostic fac- $\mathbb{D}$ tors in patients with heart failure is their response to ? treatment with vasodilators ${ }^{25}$; patients who show $\frac{0}{3}$ favourable clinical effects fare better than those who $\frac{\vec{D}}{\mathrm{D}}$ do not benefit from treatment. In so far as plasma $\bigcirc$ renin activity did not determine clinical response we $\triangle$ 
were not surprised that it also failed to predict long term survival. These findings, however, should not be construed to suggest that the renin-angiotensin system does not play a role in determining long term prognosis. All our patients were treated with converting enzyme inhibitors, which would be expected to neutralise any direct detrimental influence that angiotensin II might exert on mortality; if this neutralisation was complete, patients with a high plasma renin activity would fare as well as those with low or intermediate values. Accordingly, in order to determine if the renin-angiotensin system does exert a detrimental effect on survival, the relation between the degree of activation of the system and prognosis must be assessed in patients who are not treated with converting enzyme inhibitors. Such a deleterious role for angiotensin II has been postulated in patients with systemic hypertension and hepatic cirrhosis and, more recently, in patients with congestive heart failure, most of whom did not receive treatment with captopril or enalapril. ${ }^{26-28}$

Our findings must be interpreted cautiously. Previous claims of the value of plasma renin activity in predicting clinical events were based on studies performed in hypertensive patients who were in sodium balance while taking no drugs. ${ }^{27}$ Our patients had severe heart failure, were receiving diuretic drugs, and may not have achieved sodium balance despite great efforts to keep sodium intake and body weight constant before entry into the trial. Furthermore, patients with heart failure may alter their dependence on angiotensin II during the course of their disease if dietary intake of sodium or the dose of diuretics are changed (although such changes were not permitted in the present study) or their clinical state deteriorates. ${ }^{2930}$ Accordingly, it is unrealistic to expect that a single measurement of plasma renin activity, although determined under steady state conditions, would be able to estimate reliably the present or future role of the renin-angiotensin system in the pathogenesis of heart failure in an individual patient; hence, it cannot be used to predict the response to interventions that interfere with angiotensin II formation.

MP is the recipient of a Research Career Development Award from the National Heart, Lung and Blood Institute, Bethesda, Maryland, USA.

\section{References}

1 Packer M. Vasodilator and inotropic therapy for severe chronic heart failure: passion and skepticism. $f \mathrm{Am} \mathrm{Coll}$ Cardiol 1983; 2: 841-52.

2 Kramer BL, Massie BM, Topic N. Controlled trial of captopril in chronic heart failure: a rest and exercise hemodynamic study. Circulation 1983; 67: 807-16.
3 Captopril Multicenter Research Group. A placebocontrolled trial of captopril in refractory chronic congestive heart failure. $\mathcal{F}$ Am Coll Cardiol 1983; 2: 755-63.

4 Sharpe DN, Murphy J, Coxon R, Hannan SF. Enalapril in patients with chronic heart failure: a placebo-controlled, randomized, double-blind study. Circulation 1984; 70: 271-8.

5 Levine TB, Franciosa JA, Cohn JN. Acute and longterm response to an oral converting-enzyme inhibitor, captopril, in congestive heart failure. Circulation 1980; 62: 35-41.

6 Maslowski AH, Ikram H, Nicholls MG, Espiner EA. Haemodynamic, hormonal and electrolyte responses to captopril in resistant heart failure. Lancet 1981; i: 71-4.

7 Kluger J, Cody R, Laragh JH. The contributions of sympathetic tone and the renin-angiotensin system to severe chronic heart failure: response to specific inhibitors (prazosin and captopril). Am f Cardiol 1982; 49: $1667-74$.

8 Faxon DP, Halperin JL, Creager MA, Gavras H, Schick EC, Ryan TJ. Angiotensin inhibition in severe heart failure: acute central and limb hemodynamic effects of captopril with observations on sustained oral therapy. Am Heart $\mathcal{f} 1981$; 101: 548-56.

9 Awan NA, Evenson MK, Needham KE, Win A, Mason DT. Efficacy of oral angiotensin-converting enzyme inhibition with captopril therapy in severe chronic normotensive heart failure. Am Heart $\mathcal{F} 1981$; 101: 22-30.

10 Davis R, Ribner HS, Keung E, Sonnenblick EH, Le Jemtel TH. Treatment of chronic congestive heart failure with captopril, an oral inhibitor of angiotensinconverting enzyme. $N$ Engl $\mathcal{f}$ Med 1979; 301: 117-21.

11 Ader R, Chatterjee K, Ports T, Brundage B, Hiramatsu $B$, Parmley W. Immediate and sustained hemodynamic and clinical improvement in chronic heart failure by an oral angiotensin-converting enzyme inhibitor. Circulation 1980; 61: 931-7.

12 Packer M, Medina N, Yushak M, Meller J. Hemodynamic patterns of response during long-term captopril therapy for severe chronic heart failure. Circulation 1983; 68: 803-12.

13 Massie BM, Kramer BL, Topic N. Lack of relationship between the short-term hemodynamic effects of captopril and subsequent clinical responses. Circulation 1984; 69: 1135-41.

14 Franciosa JA, Dunkman WB, Leddy CL. Hemodynamic effects of vasodilators and long-term response in heart failure. $\mathcal{F ~ A m ~ C o l l ~ C a r d i o l ~ 1 9 8 4 ; ~ 3 : ~ 1 5 2 1 - 3 0 . ~}$

15 Jenkins AC, McKinstry DN. Review of clinical studies of hypertensive patients treated with captopril. Med $\mathcal{F}$ Aust 1979; ii (suppl 8): 32-7.

16 Cody RJ, Laragh JH. Use of captopril to estimate renin-angiotensin-aldosterone activity in the pathophysiology of chronic heart failure. Am Heart $\mathcal{F} 1982$; 104: 1184-9.

17 Murthy VS, Waldron TL, Goldberg ME. The mechanism of bradykinin potentiation after inhibition of angiotensin-converting enzyme by SQ 14,225 in conscious rabbits. Circ Res 1978; 43 (suppl 1): 40-5.

18 Cody RJ, Franklin KW, Kluger J, Laragh JH. Sympathetic responsiveness and plasma norepinephrine during therapy of chronic congestive heart failure with 
captopril. Am f Med 1982; 72: 791-7.

19 Thibonnier M, Soto ME, Menard J, Aldiger JC, Corvol P, Milliez P. Reduction of plasma and urinary vasopressin during treatment of severe hypertension by captopril. Eur f Clin Invest 1981; 11: 449-53.

20 Swales JD. Arterial wall or plasma renin in hypertension? Clin Sci 1979; 56: 293-8.

21 Thurston H, Swales JD. Comparison of angiotensin II antagonist and antiserum infusion with nephrectomy in the rat with two-kidney Goldblatt hypertension. Circ Res 1974; 35: 325-9.

22 Wenting GJ, De Bruyn JHB, Man In't Veld AJ, Woittiez AJJ, Derkx FHM, Schalekamp MADH. Hemodynamic effects of captopril in essential hypertension, renovascular hypertension and cardiac failure: correlations with short- and long-term effects on plasma renin. Am f Cardiol 1982; 49: 1453-9.

23 Riegger AJG, Lever AF, Millar JA, Morton JJ, Slack B. Correction of renal hypertension in the rat by prolonged infusion of angiotensin inhibitors. Lancet 1977; ii: 1317-9.

24 Dickinson CJ, Lawrence JR. A slowly developing pressor response to small concentrations of angiotensin: its bearing on the pathogenesis of chronic renal hyper- tension. Lancet 1963; i: 1354-6.

25 Massie B, Ports T, Chatterjee K, et al. Long-term vasodilator therapy for heart failure: clinical response and its relationship to hemodynamic measurements. Circulation 1981; 63: 269-78.

26 Cohn JN, Levine TB, Olivari MT, et al. Plasma norepinephrine as a guide to prognosis in patients with chronic congestive heart failure. $N$ Engl f Med 1984; 311: 819-23.

27 Brunner HR, Laragh JH, Baer L, et al. Essential hypertension: renin and aldosterone, heart attack and stroke. $N$ Engl f Med 1972; 286: 441-9.

28 Arroyo V, Bosch J, Gaya-Beltrán J, et al. Plasma renin activity and urinary sodium excretion as prognostic indicators in nonazotemic cirrhosis with ascites. Ann Intern Med 1981; 94: 198-201.

29 Dzau VJ, Colucci WS, Hollenberg NK, Williams GH. Relationship of the renin-angiotensin-aldosterone system to clinical state in congestive heart failure. Circulation 1981; 63: 645-51.

30 Cody RJ, Covit AB, Schaer GL, Sealey JE, Laragh JH. Renin-sodium mechanisms in chronic heart failure: response to sodium balance studies [Abstract]. Circulation 1982; 66 (suppl 2): 286. 